\title{
The Protective Effects of Omega-3 Fatty Acids and Sesame Oil on Cyclosporine-A Induced Liver Apoptosis
}

\author{
Siklosporin-A ile İndüklenen Karaciğer Apoptozuna Karşı Omega-3 Yağ Asitleri ve Susam Yağının \\ Koruyucu Etkileri
}

\author{
Azize Yasemin Göksu Erol', Aziz Bülbül2, Gülcan Avcl', Mehmet Özdemir, Özlem Akkaya ${ }^{5}$ \\ ${ }^{1}$ Department of Histology and Embryology, Faculty of Medicine, Afyon Kocatepe University, Afyonkarahisar, Turkey \\ 2Department of Physiology, Faculty of Veterinary Medicine, Afyon Kocatepe University, Afyonkarahisar, Turkey \\ ${ }^{3}$ Department of Biochemistry, Faculty of Veterinary Medicine, Afyonkocatepe University, Afyonkarahisar, Turkey \\ ${ }^{4}$ Department of Pharmacology, Faculty of Veterinary Medicine, Afyon Kocatepe University, Afyonkarahisar, Turkey \\ ${ }^{5}$ Department of Histology and Embryology, Faculty of Veterinary Medicine, Afyon Kocatepe University, Afyonkarahisar, Turkey
}

\begin{abstract}
Objective: Cyclosporine A (CSA) is the most effective and widely used immunosuppressant in solid organ transplantation and autoimmune diseases. Despite its benefits, the clinical use of CsA is limited by its nephrotoxic and hepatotoxic properties. Omega-3 fatty acids (O-3) comprise a family of unsaturated fatty acids that consist of $\alpha$-linolenic acid, eicosapentaenoic acid (EPA), and docosahexaenoic acid (DHA) which has antioxidant properties. On the other hand, sesame oil (SO) contains many constituents, including a variety of antioxidant vitamins, glycerol esters of different fatty acids, and sesamol, which was recently reported to be a potent antioxidant, etc. In our study, we aimed to investigate the potential protective effects of $O-3$ and $\mathrm{SO}$ against $\mathrm{CsA}$-induced liver apoptosis in rats.
\end{abstract}

Methods: Seven groups of 7 rats/group were treated with saline/drugs for 15 days. In group 1, only saline was given orally (Po). In group 2, subcutaneous (s.c.) CsA was administered (15 mg/kg/day). In group 3, CsA (15 mg/kg/day; sc) and SO (1 ml/kg, Po) were given. In group 4, CsA (15 mg/kg/day; sc) and O-3 (100 mg/kg; Po) were given orally. In group 5, CsA (15 mg/kg/day; sc) and SO (1 ml/kg; Po) and O-3 (100 mg/kg; Po) were given synchronously. In group 6, only SO (1 ml/kg; Po) and in group 7 only O-3 (100 mg/kg, Po) were given. $24 \mathrm{~h}$ after the last treatments animals were sacrificed and livers were extracted. Apoptotic cells in liver tissues were counted using the TUNEL method.

Results: In the group treated with CsA (Group 2), the number of apoptotic hepatocytes was significantly higher than the control group (Group 1) $(p<0.001)$. Groups treated with SO (Group 3) or O-3 (Group 4) or both (Group 5) in addition to CsA have a reduced apoptotic cell count compared to CsA-treated group, but still significantly higher than the control group ( $p<0.001$ for all 3 groups). Furthermore, the apoptotic cell count in the groups treated with $\mathrm{SO}$-alone and $\mathrm{O}$-3-alone were as low as in the control group.

Conclusion: We indicated for the first time that O-3 and $\mathrm{SO}$ treatment has a protective effect against apoptosis induced by $\mathrm{Cs} \mathrm{A}$ in rats. Moreover, our study also revealed that SO and O-3 do not show any pro-apoptotic effects on the liver. The mechanisms underlying hepatoprotection of SO and O-3 may be related to both their free radical scavenging properties and indirect effects as a regulator of antioxidative systems. Thus, SO and O-3 can be candidates as good chemoprotectants. (JAREM 2011; 1: 8-11)

Key Words: Cyclosporine A, sesame oil, omega-3 fatty acids, liver, apoptosis

\section{ÖZET}

Amaç: Siklosporin A (CsA), solid organ transplantasyonunda ve otoimmün hastalıklarda en etkili ve sıklıkla kullanılan bir immünsüpresandır. Faydalarına rağmen klinik kullanımını sınırlayan nefrotoksik ve hapatotoksik özellikleri bulunmaktadır. Omega 3 yağ asitleri (O-3), anti-oksidan özellikleri olan $\alpha$-linolenik acid, eikozapentaenoik acid (EPA) ve dokozaheksaenoik acid (DHA)'yı içeren doymamış yağ asitlerinin bir ailesini içine alır. Diğer taraftan, susam yağı (SO) birçok içeriğe sahiptir; birçok antioksidan vitaminler, farklı yağ asitlerinin gliserol esteri ve yakın zamanda potent bir antioksidan olduğu bildirilen sesamol gibi. Biz de çalışmamızda, O-3 ve SO'nun sıçan karaciğerinde CsA ile indüklenen apoptoza karşı potansiyel koruyucu etkilerini araştırdık.

Yöntemler: Herbir grupta 7 hayvan olmak üzere 7 grup sıçana 15 gün boyunca salin/ilaç uygulaması yapıldı. Grup 1'e sadece salin oral yoldan (Po) verildi. Grup 2'ye subkutan (sk) CsA uygulandı (15 mg/kg/gün). Grup 3'e CsA (15 mg/kg/gün; sk) ve SO (1 ml/kg, Po) verildi. Grup 4'te CsA (15 mg/kg/ gün; sk) ve O-3 (100 mg/kg; Po) verildi. Grup 5'e ise, CsA (15 mg/kg/gün; sk), SO (1 ml/kg, Po) ve O-3 (100 mg/kg; Po) eş zamanlı olarak verildi. Grup 6'ya sadece SO (1 ml/kg; Po) ve grup 7'ye sadece O-3 (100 mg/kg, Po) verildi. Son uygulamalardan 24 saat sonra sıçanlar sakrifiye edilip, karaciğerleri çıkarıldı. Karaciğer kesitlerinde apoptotik hücreler TUNEL yöntemi ile sayıldı.

Bulgular: CsA verilen grupta (Grup 2) apoptotik hepatosit sayısında kontrole (Grup1) kıyasla belirgin bir artış gözlendi ( $p<0.001)$. CsA'ya ek olarak, SO (Grup 3) yada O-3 (Grup 4) yada her ikisi birden (Grup 5) uygulanan gruplar, CsA uygulanan gruba göre daha düşük apoptotik hücre sayısına sahiplerdi, ancak bu sayılar kontrole göre hala yüksek değerlerde idi ( $<<0.001$; her 3 grup için). Ayrıca, sadece SO (Grup 6) ve sadece O-3 ile (Grup 7) muamele edilen gruplarda apoptotik hücre sayısı kontrol grubundaki kadar düşük olarak saptandı.

Sonuç: Susam yağı ve omega-3 uygulamasının sıçanlarda CsA ile indüklenen apoptoza karşı koruyucu etkisini ilk kez göstermiş olduk. Ayrıca çalışmamız, SO ve O-3'ün karaciğer üzerinde herhangi bir pro-apoptotik etki göstermediklerini ortaya çıkarmıştır. SO ve O-3'ün karaciğer koruyuculuğunda altta yatan mekanizmalar, hem serbest radikal temizleyici özelliklerine hem de antioksidatif sistemlerin regülatörü olarak indirek etkilerine bağlanabilir. Böylece, SO ve O-3 iyi bir kemoprotektan adayı olabilirler. (JAREM 2011; 1: 8-11)

Anahtar Sözcükler: Siklosporin A, susam yağı, omega-3 yağ asitleri, karaciğer, apoptoz

Address for Correspondence / Yazışma Adresi: Dr. Azize Yasemin Göksu Erol, İstiklal Mah. Fatih Sok. No: 21/5, 32300 Isparta, Turkey Phone: +90 5062856482 Fax: +9027221748 45 E-mail: yasemin.goksu@gmail.com
Received Date / Geliş Tarihi: 06.08.2011 Accepted Date / Kabul Tarihi: 12.09.2011 (c) Telif Hakkı 2011 AVES Yayınclık Ltd. Şti. Makale metnine www.jarem.org web sayfasından ulaşılabilir. (C) Copyright 2011 by AVES Yayınclik Ltd. Available on-line at www.jarem.org doi: 10.5152/jarem 2011.03 


\section{INTRODUCTION}

Cyclosporine A (CsA), a cyclic undecapeptide, is a potent immunosuppressive agent which has been widely used in the maintenance protocols for organ transplantation and in the treatment of autoimmune diseases. However, CsA has severe side effects which often limit the use of the drug. Among them, nephrotoxicity, hepatotoxicity and hypertension are of major importance (1).

Sesame oil (SO) is derived from the plant species Sesamum indicum L., a herbaceous annual in the Pedaliaceae family (2). SO contains many constituents, including a variety of antioxidant vitamins, glycerol esters of different fatty acids, and lignans such as sesamol, which was recently reported to be a potent antioxidant $(3,4)$. Sesamol protects against lipopolisaccaride- (3) and iron- (5) induced organ damage because of its potent antioxidative property. It is possible that SO may be important in protecting against CsA induced liver injury, as well.

Omega-3 fatty acids (O-3) comprise a family of unsaturated fatty acids that consist of $\alpha$-linolenic acid, eicosapentaenoic acid (EPA), and docosahexaenoic acid (DHA), which are essential nutrients that must be obtained from food because of the inability of humans to synthesize these fatty acids de novo (6). These fatty acids play an important role in cell membrane composition, thus influencing fluidity and cell surface biochemical signaling, as well as serving as natural ligands for certain nuclear receptors that affect gene expression. $\mathrm{O}-3$ is one of the best known antioxidants for cardiovascular disease and cognitive decline as well as cancer $(7,8)$. Moreover, O-3 has many other effects, such as reducing renal/hepatic injury; i.e. the protective effect of $\mathrm{O}-3$ has been reported against hepatic ischemia-reperfusion injury in the rat with suppression of oxidative stress (9).

Importantly, recent studies have demonstrated that nephro and hepatotoxicity induced by CsA treatment is caused by oxidative stress. Because oxidative stress is a well known apoptosis mediator, many apoptosis inhibitors have an anti-oxidant activity or increase antioxidant defense mechanisms. In our study, we aimed to investigate the potential hepatoprotective effects of O-3 fatty acid and/or SO supplementation in a rat model of CsA induced liver toxicity.

\section{METHODS}

\section{Chemicals and Reagents}

CsA was supplied from Novartis Pharma AG, Sweden. Omega 3 (Fish oil, from Menhaden, Lot: 01OM1445V) and sesame oil (Lot: MKBF0387V) were purchased from Sigma Chemical Co., USA. The purity of the compounds were over 95\%. The TUNEL assay kit (Apoptag Plus Peroxidase in Situ Apoptosis Kit (Chemicon S7101) was used.

\section{Animals and Treatments}

Forty-nine adult male Wistar-Albino rats weighing 150-200 g obtained from Afyon Kocatepe University Laboratory Animal Breeding Research Center were used in this study. All animals were kept under the same laboratory conditions of temperature $\left(25 \pm 2^{\circ} \mathrm{C}\right)$ and lighting (12: $12 \mathrm{~h}$ light:dark cycle) and were given free access to standard laboratory chow and tap water. All rats were allowed to acclimatize for 1 week prior to experimentation. All experimental procedures involving animals were approved by the Ethic Committee of Afyon Kocatepe University, Afyonkarahisar, Turkey.
The animals were randomly divided into seven groups containing seven rats in each. 15 consecutive days of saline/drug administration was performed in each group to see the long term (chronic) effects of the drugs. Group 1 served as controls and received physiological saline orally (Po) alone. Group 2 was treated with subcutaneously (s.c.) with CsA at a dose of $15 \mathrm{mg} / \mathrm{kg} /$ day, which is well documented to induce nephro- and hepatotoxicity. In group 3, CsA (15 mg/kg/day; sc) and SO (1 ml/kg; Po) were given. In group 4, CsA (15 mg/kg/day; sc) and O-3 (100 mg/kg; Po) dissolved in an equal volume of olive oil were given. In group 5, CsA (15 mg/kg/day; sc), SO (1 ml/kg; Po) and O-3 (100 mg/kg; Po) were given synchronously. In group $6, \mathrm{SO}(1 \mathrm{ml} / \mathrm{kg}$; Po) alone was given. In group 7, O-3 (100 mg/kg; Po) alone was administered. The animals were killed $24 \mathrm{~h}$ after the last dose of the treatments. The dose of each drug adopted in this study was based on the preliminary studies.

\section{Measurement of Hepatocyte Apoptosis}

Apoptotic hepatocytes were detected by terminal deoxynucleotidyl transferase-mediated dUTP nick end-labeling (TUNEL) staining using a commercial ready-to-use kit (Millipore, Germany). Following deparaffinization and rehydration, $4 \mu \mathrm{m}$ liver tissue sections were treated with proteinase K in PBS $(10 \mu \mathrm{g} / \mathrm{ml})$ for $30 \mathrm{~min}$, and after washing with PBS, these sections were incubated with the TUNEL reaction mixture for $60 \mathrm{~min}$ at $37^{\circ} \mathrm{C}$. Following converter-POD addition and diaminobenzidine (DAB) substrate reaction, these sections were eventually examined under light microscope and photographs were taken. The evaluation was performed as follows; in each slide the apoptotic cell numbers were counted in 5 areas on $\times 20$ objective and then were divided into 5 to obtain the mean value for each animal and the mean numbers for each animal were noted in every group.

\section{Statistical Analysis}

Data were expressed as mean \pm S.E.M. and were analyzed with SPSS, Version 12.0 software. Differences between group means were calculated by the Duncan test. Results were considered statistically significant when $\mathrm{p}<0.05$.

\section{RESULTS}

Effects of Sesame Oil and Omega 3 on Hepatocyte Apoptosis Liver sections were stained using the TUNEL method. In the control rats, apoptotic hepatocytes could hardly be observed in the liver sections. $24 \mathrm{~h}$ following 15 days of CsA treatment, extensive and large number of TUNEL positive hepatocytes could be observed. In the group treated with CsA, the number of apoptotic hepatocytes was significantly higher than the control group $(\mathrm{p}<0.001)$ (Table 1). Groups treated with $\mathrm{O}-3$ or $\mathrm{SO}$ or both in addition to CsA have a reduced apoptotic cell count compared to the CsA-treated group, but still significantly higher than the control group ( $p<0.001$ for both). Furthermore, the apoptotic cell count in the groups treated with $\mathrm{O} 3$-alone and SO-alone were very close to the control group (Table 1).

\section{DISCUSSION}

Cyclosporine A, a cyclic decapeptide obtained from extracts of soil fungus Tolypocladium inflatum gams, is the most effective and widely used first-line immunosuppressant in solid organ transplantation and autoimmune diseases (10). Despite its 


\section{Table 1. The apoptotic cell numbers as mean \pm SEM values of liver tissues in 7 group of rats as 7 rats/group}

\begin{tabular}{|c|c|c|c|c|c|c|c|}
\hline & G1 Control & $\begin{array}{l}\text { G2 } \\
\text { CsA alone }\end{array}$ & $\begin{array}{l}\mathrm{G} 3 \\
\mathrm{CsA}+\mathrm{SO}\end{array}$ & $\begin{array}{l}\mathrm{G} 4 \\
\mathrm{CsA}+\mathrm{O}-3\end{array}$ & $\begin{array}{l}\mathrm{G} 5 \\
\mathrm{CsA}+\mathrm{SO}+\mathrm{O}-3\end{array}$ & $\begin{array}{l}\text { G6 } \\
\text { SO alone }\end{array}$ & $\begin{array}{l}\text { G7 } \\
\text { O-3 alone }\end{array}$ \\
\hline $\begin{array}{l}\text { The mean apoptotic } \\
\text { hepatocyte count }\end{array}$ & $1.13 \pm 0.16$ & $6.36 \pm 0.68$ & $3.80 \pm 0.38$ & $3.33 \pm 0.53$ & $2.73 \pm 0.27$ & $1.43 \pm 0.31$ & $1.33 \pm 0.24$ \\
\hline
\end{tabular}

benefits, the clinical use of CsA is limited by its nephrotoxic amd hepatotoxic properties.

Liver is well known to be the major organ responsible for the metabolism of drugs and toxic chemicals, and therefore is the primary target organ for nearly all the toxic chemicals (11-13). Excessive dose exposure to various pharmacological or chemical substances may induce acute liver injury characterized by abnormality of hepatic function, and degeneration, necrosis or apoptosis of hepatocytes (14-17). Attempts to find some effective therapeutical methods for the treatment of toxic liver injuries are considered very important in clinical situations. Therefore, it is valuable to identify natural drugs or compounds that can antagonize the deleterious action of free radicals and act as an antioxidant to protect hepatocytes from damage.

For example, melatonin was found to be an effective antioxidant substance in preventing or attenuating hepatotoxicity induced by CsA, supporting the key role of oxidative damage in the pathogenesis of liver injury, and natural or artificial antioxidants would contribute greatly to the prevention and treatment of liver injury in the future (18-21). SO and O-3 have been shown to possess free radical scavenging properties and protect oxidative stressinduced toxic injuries. They were also reported to have efficacy in ameliorating various hepatotoxin-induced hepatocellular damage in previous studies. So we aimed to investigate the potential protective effects of $\mathrm{O}-3$ fatty acids and $\mathrm{SO}$ on hepatic damage in terms of apoptosis of hepatocytes caused by CsA in rats.

In our study, chronically administered low dose CsA caused highly increased apoptosis of hepatocytes in rats. We also found that, when CsA was given in combination with $\mathrm{O}-3$ or $\mathrm{SO}$, there was a significant reduction in the apoptotic cell count $(p<0.001)$. However the mean apoptotic hepatocyte number was still higher than the control. That means although there was a reduction in the apoptotic effect of CsA with O-3 and SO, the result was not a return to the completely normal values of the control group.

Meanwhile, when CsA, O-3 and SO were given together, the apoptotic cell count was not statistically different from $\mathrm{CsA}+\mathrm{O}-3$ or $\mathrm{CsA}+\mathrm{SO}$, which indicates that $\mathrm{O}-3$ and $\mathrm{SO}$ do not show additional effects when given together for inhibiting apoptosis. Furthermore, in the groups treated with $\mathrm{O} 3$-alone and $\mathrm{SO}$-alone, the number of apoptotic hepatocytes were very low similar to the control group, proving that $\mathrm{O}-3$ and $\mathrm{SO}$ do not have any proapoptotic effects on the liver.

Supporting our findings, a hepatoprotective effect of O-3 fatty acids has been demonstrated in a study by Schmocker et al. (22), in which Fat1 mice (genetically engineered to endogenously convert omega- 6 fatty acids to omega-3 fatty acids) were subjected to the D-galactosamine/lipopolysaccharide model of acute hepatitis. It has also been reported that the hepatocellular injury after common bile duct ligation was reduced using $\bigcirc-3$ fatty acids (23).

On the other hand, SO was found to protect against oxidative stress and hepatic injury after cecal ligation and puncture in rats, which may be attributable to the antioxidant components in $\mathrm{SO}$ $(24,25)$. Furthermore, Hsu et al. reported that SO attenuates cisplatin induced hepatic and renal injuries by inhibiting nitric oxide-associated lipid peroxidation in mice (26).

Further findings in our study were; in the groups treated with $\bigcirc$ 3-alone and SO-alone, the number of apoptotic liver cells was very low as in the control group, suggesting that $\mathrm{O}-3$ and $\mathrm{SO}$ do not have any pro-apoptotic effects on the liver. In this context, there is not many studies on the apoptosis-O-3-SO relationship in the literature. However, several findings indicate that $\mathrm{O}-3$ and SO may have apoptotic effects on cancer cells, probably by activation of various mechanisms. DHA was reported to induce apoptosis via the Bax-independent pathway in human myeloid leukemia HL-60 cells (27). O-3 fatty acids were also found to induce apoptosis in human breast cancer cells and mouse mammary tissue (28). Some cytotoxic characteristics of products from oxidation of sesamol, an antioxidative constituent of sesame oil in rat thymocytes and human leukemia K562 cells, were also reported, indicating the apoptosis-inducing action of SO (29). Sesamol has been reported to have cytotoxic effects against cancer. The sesame seed oil constituent, sesamol, induces growth arrest and apoptosis of cancer and cardiovascular cells (30).

Thus, we may interpret these conflicting findings in this way; O-3 and SO may have proapoptotic effects in pathological conditions, such as cancer. Several apoptotic pathways may be activated through interaction of cancer cells with $\mathrm{O}-3$ and $\mathrm{SO}$, but in normal tissue, this is not valid.

Finally, in our study, we indicated for the first time that $\bigcirc-3$ and $\mathrm{SO}$ treatment has a potent protective effect against apoptosis induced by CsA in rats, as revealed by remarkable decrease in apoptotic cells in the liver. The mechanisms underlying hepatoprotection of $\mathrm{O}-3$ and $\mathrm{SO}$ may be related to both their radical scavenging properties and indirect effects as a regulator of antioxidative systems, but more studies should be carried out in the future. In conclusion, our investigation provided convincing data that $\mathrm{O}-3$ and SO have impressive hepatoprotective effects on acute liver injuries induced by CsA, which might be considered to be therapeutic in clinical situations.

Acknowledgement: This study was supported by funds from The Scientific Research Council of Afyon Kocatepe University (AKU, BAPK, Project no:10.REK.04) 
Conflict of interest: No conflict of interest was declared by the authors.

\section{REFERENCES}

1. Philip AT, Gerson B. Toxicology and adverse effects of drugs used for immunosuppression in organ transplantation. Clin Lab Med 1998; 18: 755-65.

2. Sugano $M$, Akimoto KA. Multifunctional gift from nature. J Chin Nutr Soc 1993; 18: 1-11.

3. Hsu DZ, Li YH, Chu PY, Chien SP, Chuang YC, Liu MY. Attenuation of endotoxin-induced oxidative stress and multiple organ injury by 3,4-methylenedioxyphenol in rats. Shock 2006; 25: 300-5. [CrossRef]

4. Namiki M. Nutraceutical functions of sesame: a review. Crit Rev Food Sci Nutr 2007; 47: 651-73. [CrossRef]

5. Hsu DZ, Chien SP, Chen KT, Liu MY. The effect of sesamol on systemic oxidative stress and hepatic dysfunction in acutely iron-intoxicated mice. Shock 2007; 28: 596-601.

6. Simopoulos AP. Omega-3 fatty acids and athletics. Curr Sports Med Rep 2007; 6: 230-6. [CrossRef]

7. Leaf A, Weber PC. Cardiovascular effects of n-3 fatty acids. N Engl J Med 1988; 318: 549-57. [CrossRef]

8. Lee TH, Hoover RL, Williams JD, Sperling RI, Ravalese J 3rd, Spur BW, et al. Effect of dietary enrichment with eicosapentaenoic and docosahexaenoic acids on in vitro neutrophil and monocyte leukotriene generation and neutrophil function, N Engl J Med 1985; 312: 1217-24. [CrossRef]

9. Zúñiga J, Venegas F, Villarreal M, Núñez D, Chandía M, Valenzuela $\mathrm{R}$, et al. Protection against in vivo liver ischemia-reperfusion injury by $\mathrm{n}-3$ long-chain polyunsaturated fatty acids in the rat. Free Radic Res 2010; 44: 854-63. [CrossRef]

10. Padi S, Chopra K. Selective angiotensin P type 1 receptor blockade ameliorates cyclosporine nephrotoxicity. Pharmacol Res 2002; 45: 413-20. [CrossRef]

11. Larrey D. Drug-induced liver diseases. J Hepatol 2000; 32: 77-88. [CrossRef]

12. Bissel DM, Gores GJ, Laskin DL, Hoorhagle JH. Drug-induced liver injury mechanisms and test systems. Hepatology 2001; 33: 1009-13. [CrossRef]

13. Lee WM. Drug-induced hepatotoxicity. N Engl J Med 2003; 349: 474-81. [CrossRef]

14. Higuchi $H$, Gores GJ. Mechanisms of liver injury: an overview. Curr Mol Med 2003; 3: 483-90. [CrossRef]

15. Kaplowitz N. Biochemical and cellular mechanisms of toxic liver injury. Semin Liver Dis 2002; 22: 137-44. [CrossRef]

16. Basu S. Carbon tetrachloride-induced lipid peroxidation: eicosanoid formation and their regulation by antioxidant nutrients. Toxicology 2003; 189: 113-27. [CrossRef]
17. Nelson SD. Molecular mechanisms of the hepatotoxicity caused by acetaminophen. Semin Liver Dis 1990; 10: 267-78. [CrossRef]

18. El-Sokkary GH, Abdel-Rahman GH, Kamel ES. Melatonin protects against lead-induced hepatic and renal toxicity in male rats. Toxicology 2005; 213: 25-33. [CrossRef]

19. Jaeschke $\mathrm{H}$. Reactive oxygen and mechanisms of inflammatory liver injury. J Gastroenterol Hepatol 2000; 15: 718-24. [CrossRef]

20. Hensley K, Robinson K, Gabbita SP, Salsman S, Floyd RA. Reactive oxygen species, cell signaling, and cell injury. Free Radic Biol Med 2000; 28: 1456-62. [CrossRef]

21. Castro L, Freeman BA. Reactive oxygen species in human health and disease. Nutrition 2001; 17: 161-5. [CrossRef]

22. Schmocker C, Weylandt KH, Kahlke L, Wang J, Lobeck H, Tiegs G, et al. Omega-3 fatty acids alleviate chemically induced acute hepatitis by suppression of cytokines. Hepatology 2007; 45: 864-9. [CrossRef]

23. Lee S, Kim S, Le HD, Meisel J, Strijbosch RA, Nose V, et al. Reduction of hepatocellular injury after common bile duct ligation using omega-3 fatty acids. J Pediatr Surg 2008; 43: 2010-5. [CrossRef]

24. Hsu DZ, Li YH, Chien SP, Liu MY. Effects of sesame oil on oxidative stress and hepatic injury after cecal ligation and puncture in rats. Shock 2004; 21: 466-9. [CrossRef]

25. Chavali SR, Utsunomiya T, Forse RA. Increased survival after cecal ligation and puncture in mice consuming diets enriched with sesame seed oil. Crit Care Med 2001; 29: 140-3. [CrossRef]

26. Hsu DZ, Chen KT, Lin TH, Li YH, Liu MY. Sesame oil attenuates Cisplatin induced hepatic and renal injuries by inhibiting nitric oxide-associated lipid peroxidation in mice. Shock 2007; 27: 199204. [CrossRef]

27. Miura Y, Takahara K, Murata Y, Utsumi K, Tada M, Takahata K. Docosahexaenoic acid induces apoptosis via the Bax-independent pathway in HL-60 cells. Biosci Biotechnol Biochem 2004; 68: 2415-7. [CrossRef]

28. Sun H, Hu Y, Gu Z, Owens RT, Chen YQ, Edwards IJ. Omega-3 fatty acids induce apoptosis in human breast cancer cells and mouse mammary tissue through syndecan-1 inhibition of the MEK-Erk pathway. Carcinogenesis. $2011 \mathrm{Jul}$ 18. [Epub ahead of print]

29. Fujimoto A, Shingai $Y$, Oyama TB, Kawanai T, Hashimoto E, Koizumi $K$, et al. Apoptosis-inducing action of two products from oxidation of sesamol, an antioxidative constituent of sesame oil: a possible cytotoxicity of oxidized antioxidant. Toxicol In Vitro 2010; 24: 1720-6. [CrossRef]

30. Jacklin A, Ratledge C, Welham K, Bilko D, Newton CJ. The sesame seed oil constituent, sesamol, induces growth arrest and apoptosis of cancer and cardiovascular cells. Ann N Y Acad Sci 2003; 1010: 374-80. [CrossRef] 